\title{
1-Methylcyclopropene (1-MCP) effects on natural disease resistance in stored sweetpotato
}

Running title: Effects of 1-methylcyclopropene treatment on diseases in sweetpotato

\author{
Robert S. Amoah ${ }^{\mathrm{a}}$ and Leon A. Terry ${ }^{\mathrm{b}} *$
}

${ }^{a}$ Department of Agricultural Engineering, University of Cape Coast, Cape Coast, Ghana.

${ }^{\mathrm{b}}$ Plant Science Laboratory, Cranfield University, Bedfordshire, MK 43 0AL, UK.

\section{Address for Correspondence}

Prof. Leon Terry

Plant Science Laboratory, Cranfield University, Bedfordshire, MK 43 OAL, UK.

Email: 1.a.terry@cranfield.ac.uk

\begin{abstract}
BACKGROUND: The potential of 1-methylcyclopropene (1-MCP) to maintain postharvest storage of sweetpotato was studied. In two separate experiments, the orange-fleshed sweetpotato cv. Covington was fumigated with 1-MCP $\left(1.0 \mu \mathrm{L} \mathrm{L}^{-1}, 24 \mathrm{~h}\right)$ and roots stored at $15{ }^{\circ} \mathrm{C}$. During storage, samples were evaluated for the respiration rate, sprout growth, weight loss, incidence of decay and changes in dry matter. The roots were further assayed for the temporal changes in individual non-structural carbohydrates and phenolic compounds in the skin and flesh tissues of the proximal (stem end), middle, and distal (root end) regions.
\end{abstract}


RESULTS: 1-MCP treatment significantly reduced root weight loss and decay but respiration rate and non-structural carbohydrates were not affected. No sprouting was recorded irrespective of the treatment. 1-MCP transiently suppressed the accumulation of individual phenolic compounds, especially in the middle and distal segments. This accentuated the proximal dominance of phenolic compounds. Isochlorogenic acid A and chlorogenic acid were the dominant phenolics in the skin and flesh tissues, respectively.

CONCLUSION: 1-MCP treatment may have anti-decay effect and reduce weight loss. Therefore, storage trials which involve the use of continuous ethylene supplementation to inhibit sprout growth may be combined with 1-MCP to alleviate ethylene-induced weight loss and decay in sweetpotato.

Keywords: respiration, decay, weight loss, sugars, phenolics

\section{INTRODUCTION}

Sweetpotato [Ipomoea batatas (L.) Lam.] has great potential for improving food security in the tropics owing to the numerous agronomic advantages and nutritional benefits ${ }^{1}$. In many parts of Africa sweetpotato, the beta-carotene-rich orange-flesh varieties are being promoted as a public health tool for improved child and maternal nutrition. 'Covington' is an orangefleshed, smooth-skinned and rose-coloured sweetpotato variety developed by North Carolina State University. It is moderately resistant to many diseases and has an agreeable flavour, making it a preferred table stock ${ }^{2}$ and for food security initiatives.

Despite the growing importance, sweetpotato roots have an inherently short postharvest storage life of about two to three weeks at ambient temperature ${ }^{3}$. Root decay, represents the 
most significant cause of economic loss in sweetpotato ${ }^{4}$. In addition, the dormancy phase is readily abbreviated by storage in favourable growth conditions; and this is followed by excessive sprout growth, which reduces the marketable value. Sprout growth in both potato (Solanum tuberosum ) and sweetpotato can be inhibited by sustained exposure to exogenous ethylene $^{5-7}$. However, ethylene has detrimental effects on both crops. In potato, the use of ethylene to suppress sprout growth can trigger the accumulation of sugars and leads to darkening of the fry colour. This deleterious effect can be reduced by manipulating the ethylene scheduling ${ }^{5,8}$. Alternatively, pre-treatment of potato with the ethylene binding inhibitor 1-methylcyclopropene $\left(1.0 \mu \mathrm{L} \mathrm{L}^{-1}\right)$ can alleviate the darkening effect ${ }^{5,6}$. Other studies demonstrate that treatment of the onion cv. Sherpa with 1-MCP $\left(1.0 \mu \mathrm{L} \mathrm{L}^{-1}\right)$ before or after curing, elicits a similar effect of suppressing sprout growth as using ethylene alone $\mathrm{e}^{9,10}$.

In sweetpotato, the use of ethylene to suppress sprouting also promotes root decay ${ }^{7,11}$. The potential effect of 1-MCP on sweetpotato storage was investigated by Cheema et al. ${ }^{12}$ who found that the concentration of $625 \mathrm{~nL} \mathrm{~L}^{-1}$ applied for $24 \mathrm{~h}$ and stored at $25{ }^{\circ} \mathrm{C}$ inhibited sprout growth in sweetpotato cvs. Bushbuck and Ibees for at least four weeks. This offers a potential alternative approach to continuous exposure to exogenous ethylene. Thus, the work reported herein, investigated the effects of 1-MCP on sweetpotato decay and physiology in relation to the temporal and spatial flux of major individual carbohydrates and phenolic compounds during storage.

\section{EXPERIMENTAL}

\section{Plant material}


Experiments were conducted on two different consignments of sweetpotato cv. Covington to elucidate the effect of 1-MCP during cold storage at $15{ }^{\circ} \mathrm{C}$. Both old and freshly stored roots were tested. Roots for Experiment 1 were cultivated in the USA (Barnes Farming) and delivered through Barfoots of Botley Ltd. (W. Sussex, UK). After harvesting in November 2010 , the roots were cured $\left(30{ }^{\circ} \mathrm{C}, 95 \%\right.$ relative humidity) and stored at $14{ }^{\circ} \mathrm{C}$ for $c a$. seven months before being received (July, 2011) at Cranfield University (CU), UK. Roots for the second experiment were sourced from Portugal where they were planted in June 2011, harvested in October 2011, and also cured under similar conditions as described earlier and according to standard commercial practice and stored at $14{ }^{\circ} \mathrm{C}$ at Barfoots of Botley for two weeks before being delivered to $\mathrm{CU}$ for the trial.

\section{Experimental design}

The consignment for each experiment was initially divided into two lots; the lots were further divided into three replicates each and treated separately in water-sealed $264 \mathrm{~L}$ polypropylene boxes at $15{ }^{\circ} \mathrm{C}$. In each case, one lot (in triplicate) was fumigated with 1 -MCP $\left(1.0 \mu \mathrm{L} \mathrm{L}^{-1}, 24\right.$ h) while the other (also in triplicate) served as the untreated control. Each replicate box contained two sub-samples designated as destructive sub-samples ( $n=15$ and 30 in Experiment 1 and Experiment 2, respectively) and non-destructive sub-samples ( $n=10$ and 20 in the respective experiments). The non-destructively evaluated sub-samples were distinguished by tagging individual roots and assessed periodically for weight loss, decay and sprouting. The destructive sub-samples were further assessed for respiration rate, followed by biochemical assays (non-structural sugars and phenolics). Baseline samples (as received at the beginning of the experiment) were assessed before 1-MCP treatment and then at periodic intervals after the treatment. 


\section{1-MCP treatment}

1-MCP was applied as described by Chope et al. ${ }^{13}$ with slight modifications. To release the concentration of $1.0 \mu \mathrm{L} \mathrm{L}^{-1}$ of 1-MCP gas, $1.47 \mathrm{~g}$ of 1-MCP powder (Smart-fresh, $0.14 \%$ Rohm and Haas PA) was weighed into three $50 \mathrm{~mL}$ conical flasks and sealed with Nescofilm (Bando Chemical Ind. Ltd., Kobe, Japan). To each flask, $5 \mathrm{~mL}$ of warm water $\left(\mathrm{ca} .50{ }^{\circ} \mathrm{C}\right)$ was injected through the Nescofilm using a needle and syringe, shaken to mix and quickly placed in the storage boxes for $24 \mathrm{~h}$. An $8 \times 8 \mathrm{~cm}$ electric fan (Nidec beta SL, Nidec, Japan) was installed in each box to circulate the released gas. Periodically, the headspace gas in the boxes were analysed by repeated withdrawal and injection into a gas chromatograph (GC model 8340, DP800 integrator, Carlos Erba Instruments, Herts., UK) equipped with a flame ionisation detector (FID). The 1-MCP treatments achieved a mean concentration of $1.02 \mu \mathrm{L}$ $\mathrm{L}^{-1}$ (data not shown). After $24 \mathrm{~h}$, the boxes were opened and the roots transferred into air storage in a temperature controlled room at $15{ }^{\circ} \mathrm{C}$. Alongside the $1-\mathrm{MCP}$ treatment, the control roots were kept in other boxes under identical conditions.

\section{Non-destructive assessments}

The non-destructively tested roots were individually numbered and repeatedly assessed for weight loss, cumulative decay and sprout growth as described by Amoah et al. ${ }^{7}$. In Experiment 2, some control roots were also stored at $25{ }^{\circ} \mathrm{C}$ to check the effect of temperature on sprouting.

\section{Measurement of respiration rate}


Roots ( $\mathrm{n}=9$ and 12 and in Experiment 1 and Experiment 2, respectively) selected for biochemical assays were initially assessed for their respiration rates using a Sable Respirometry System (Model 1.3.8 Pro, Sable Systems International, NV, USA) as described by Amoah et al. ${ }^{7}$.

\section{Sample preparation for biochemical assays}

After measuring respiration rates, roots were immediately washed in running tap water and dried with a soft paper towel. Each root was then cut into the proximal, middle and distal segments (each segment was approximately a third of the total root length). The segments were manually peeled with a sharp knife to obtain two types of tissue: skin (comprising the periderm, $c a$. 1.0-1.5 mm deep) and flesh (comprising the cortex and pith). The skin and flesh tissues were snap-frozen in liquid nitrogen, each divided into two and stored at $-40{ }^{\circ} \mathrm{C}$ and $80{ }^{\circ} \mathrm{C}$ respectively, until further analysis. Approximately $10 \mathrm{~g}$ of the frozen tissue $\left(-40{ }^{\circ} \mathrm{C}\right)$ were weighed (fresh weight, FW) and freeze-dried (Scan Vac, Västerås, Sweden) in the dark for seven days. After lyophilisation, the samples were re-weighed to obtain the dry weight (DW). The dry matter content (\%) was subsequently calculated on fresh weight basis. The samples were then ground to powder and stored at $-40{ }^{\circ} \mathrm{C}$ in readiness for individual nonstructural carbohydrates and phenolics assays.

\section{Extraction and quantification of non-structural carbohydrates and phenolic compounds}

Individual soluble sugars and phenolic compounds were extracted and quantified according to the protocols described by Amoah et al. ${ }^{7}$. The individual phenolic compounds in the samples of Experiment 1 were calibrated against chlorogenic acid and measured in terms of 
chlorogenic acid equivalence on fresh weight basis. In Experiment 2, however, the individual phenolic compounds were calibrated with their respective pure standards.

\section{Statistical analysis}

All data was first subjected to Shapiro-Wilk normality test and plotted for residuals to verify the assumptions for the Analysis of Variance (ANOVA). The ANOVA tables were generated using GenStat for Windows, Version 14 (VSN International Ltd., Herts., UK) and used to identify statistically significant trends. The means between treatments were separated with the Least Significant Difference (LSD) at $\mathrm{P}=0.05$.

\section{RESULTS}

\section{1-MCP had no effect on respiration rate and sprouting}

Respiration in the older root stock (Experiment 1: measured $70 \mathrm{~d}$ after 1-MCP treatment) remained fairly constant at a mean value $3.87 \times 10^{-6} \mathrm{~g} \mathrm{~kg}^{-1} \mathrm{~s}^{-1}$ (Fig. 1). On the other hand, initial respiration rate of the much fresher roots (Experiment 2) was higher than that of the older roots but it gradually declined from the mean value $8.90 \times 10^{-6} \mathrm{~g} \mathrm{~kg}^{-1} \mathrm{~s}^{-1}$ at the beginning of storage to $3.67 \times 10^{-6} \mathrm{~g} \mathrm{~kg}^{-1} \mathrm{~s}^{-1}$ after $130 \mathrm{~d}$ of storage. In both experiments, however, no effect of 1-MCP treatment was observed on the respiration rate of the roots. Also, in both 1-MCP treated and untreated roots, no incidence of sprout emergence was observed as long as they remained in cold storage at $15^{\circ} \mathrm{C}$.

\section{1-MCP reduced root decay}


Root decay was significantly reduced by $1-\mathrm{MCP}$ in both experiments. This was more profound in the older root stock in Experiment 1 where at $84 \mathrm{~d}$ after treatment with 1-MCP, disease severity was reduced by half to about $23.3 \%$ compared to $46.7 \%$ in the untreated roots (Fig. 2). A similar pattern was observed in Experiment 2, although decay was less pronounced. In this case, decay was only marginally reduced by 1-MCP during the first $100 \mathrm{~d}$ after treatment. During subsequent storage, however, 1-MCP (5\% decay at 112 d) significantly decreased root decay compared to the control (20\% decay at $112 \mathrm{~d})$. The earliest incidence of decay in Experiment 1 was three weeks after 1-MCP treatment; and decay was observed in both 1-MCP-treated and control roots. However, the fresher roots of Experiment 2 started decaying much later at seven weeks after 1-MCP treatment and subsequent storage. Generally, two distinct types of root decay were observed; tip (proximal) rot and end (distal) rot. Both types of rot initiated from the respective root ends and progressed through the middle to the opposite ends.

\section{1-MCP reduced weight loss}

Weight loss in 1-MCP treatment was reduced by $c a$. 1.8-fold in the old root stock (Experiment 1) and by ca. 1.3-fold in the fresher roots (Experiment 2) (Fig. 3). Thus at $84 \mathrm{~d}$, the untreated roots in Experiment 1 had lost $c a .41 \%$ weight as against $c a .23 \%$ in the 1MCP-treated roots. Likewise, in Experiment 2, the control roots lost weight at a much faster rate $(c a .32 \%$ at $112 \mathrm{~d})$ than the 1-MCP-treated roots $(c a .21 \%$ at $112 \mathrm{~d})$. The rate of root decay was correlated with the weight loss. It was noted that decay increased concomitantly to weight loss [Experiment 1: $\mathrm{R}^{2}=0.90$; Experiment 2: $\mathrm{R}^{2}=0.86$ ]

\section{Effect of 1-MCP on dry matter}


The effect of 1-MCP on dry matter weight (percentage in the fresh root weight) was not consistent between the two experiments (Supplementary Fig. 1). In the older root stock (Experiment 1), dry matter weight of 1-MCP-treated roots $\left(211 \mathrm{~g} \mathrm{~kg}^{-1}\right)$ was not significantly different from that of the untreated roots $\left(206 \mathrm{~g} \mathrm{~kg}^{-1}\right)$. A contrary effect was, however, observed in the fresh roots in Experiment 2 as dry matter was significantly lower in roots with 1-MCP treatment $\left(243 \mathrm{~g} \mathrm{~kg}^{-1}\right)$ than the untreated roots $\left(253 \mathrm{~g} \mathrm{~kg}^{-1}\right)$. Skin dry matter content (223 $\mathrm{g} \mathrm{kg}^{-1}$ and $262 \mathrm{~g} \mathrm{~kg}^{-1}$ in Experiment 1 and Experiment 2, respectively) was significantly higher than the respective flesh dry weights $\left(194 \mathrm{~g} \mathrm{~kg}^{-1}\right.$ and $237 \mathrm{~g} \mathrm{~kg}^{-1}$ in Experiment 1 and Experiment 2, respectively). Roots in Experiment 1 were further assayed for the spatial gradient of dry matter across the root length. The mean dry matter content (for pooled skin and flesh tissues) at the proximal $\left(210 \mathrm{~g} \mathrm{~kg}^{-1}\right)$, middle $\left(206 \mathrm{~g} \mathrm{~kg}^{-1}\right)$ and the distal $\left(209 \mathrm{~g} \mathrm{~kg}^{-1}\right)$ root sections were not significantly different.

\section{1-MCP did not affect non-structural carbohydrates}

Individual non-structural carbohydrates were analysed separately in flesh and skin tissues across the proximal, middle and distal sections. During storage, all the reducing sugars significantly declined $(\mathrm{P}<0.001)$ in both $1-\mathrm{MCP}$ treated and control roots while sucrose content remained relatively stable. In both experiments, no significant effect of 1-MCP was observed on the contents of sugar across the spatial gradient of the roots (Supplementary Fig. 2 and 3) except maltose in Experiment 1 which was more concentrated in the skin of roots treated with 1-MCP than the control $(\mathrm{p}=0.004)$.

The mean fresh weight concentration of maltose, fructose, glucose and sucrose in the flesh tissues at the start of Experiment 1 were 2420, 5510, 8340 and $46930 \mathrm{mg} \mathrm{kg}^{-1}$, respectively. Their corresponding concentrations in the skin were 2770, 3080, 3210, $38050 \mathrm{mg} \mathrm{kg}^{-1}$, respectively. Thus, their corresponding values in the skin were lower except for maltose. 
During subsequent storage, however, maltose was found in approximately similar concentration in the skin as the flesh tissues. The mean concentrations of the sugars in the roots from Experiment 2 were significantly higher than those in Experiment 1. Initial fructose, glucose and sucrose content in the flesh tissues were 13710, 15420 and $40660 \mathrm{mg}$ $\mathrm{kg}^{-1}$ while the corresponding values in the skin were 8110,6850 and $41860 \mathrm{mg} \mathrm{kg}^{-1}$, respectively. However, maltose was not detected in Experiment 2, irrespective of the treatment.

\section{Effect of 1-MCP on phenolic compounds}

\section{Experiment 1 (Old root stock of 'Covington')}

Total phenolics content (measured as chlorogenic acid equivalence on fresh weight basis) in the skin $\left(2290 \mathrm{mg} \mathrm{kg}^{-1}\right)$ was ca. 11-fold greater than the flesh content $\left(200 \mathrm{mg} \mathrm{kg}^{-1}\right)$. Also, total phenolics concentration in the proximal section $\left(2960 \mathrm{mg} \mathrm{kg}^{-1}\right.$ ) of the roots was significantly greater $(\mathrm{P}<0.001)$ than either the middle $\left(1890 \mathrm{mg} \mathrm{kg}^{-1}\right)$ or distal sections (2030 mg kg-1). The individual phenolic compounds were also not uniformly distributed across the spatial gradient (Fig. $5 \&$ Supplementary Fig. 4). Isochlorogenic acid A (3,5-di-Ocaffeoylquinic acid) was the most abundant phenolic compound in the periderm $\left(960 \mathrm{mg} \mathrm{kg}^{-}\right.$ ${ }^{1}$ ), followed by chlorogenic acid (5-O-caffeoylquinic acid; $450 \mathrm{mg} \mathrm{kg}{ }^{-1}$ ). Conversely, chlorogenic acid was the dominant phenolic in the flesh tissues $\left(130 \mathrm{mg} \mathrm{kg}^{-1}\right)$, followed by isochlorogenic acid A (60 mg kg-1) (Fig. 5 \& Supplementary Fig. 4). Ferulic and coumaric acids were only present in trace quantities. Chlorogenic acid and its isomers were significantly more concentrated in the proximal section of the roots $(\mathrm{P}<0.05)$ except for isochlorogenic acid $\mathrm{C}(4,5$ di-caffeoylquinic acid) whose content in the flesh tissue did not vary significantly across the root sections $(\mathrm{P}=0.315)$. The skin content of caffeic acid was 
evenly distributed between the proximal and distal sections (560 $\mathrm{mg} \mathrm{kg}^{-1}$ ) with the middle section accumulating the least concentration. However, in the flesh tissues, caffeic acid was more abundant in the proximal than the middle and distal sections of the roots (Fig. 5).

1-MCP significantly suppressed both total and individual phenolic contents in the tissues across the root sections except the proximal skin tissues (Fig. 5). Thus, the inhibition of phenolics by 1-MCP was more profound in the middle and distal tissues, accentuating the proximal dominance of phenolics. However, the suppression of phenolic compounds by 1MCP was transient as the effect diminished with time (Fig. 5 \& Supplementary Fig. 5).

\section{Experiment 2 (Fresh root stock of 'Covington')}

As observed in Experiment 1, isochlorogenic acid A was the dominant phenolic in the skin tissues (1870 mg kg ${ }^{-1}$ ) followed by chlorogenic acid (1010 $\mathrm{mg} \mathrm{kg}^{-1}$ ) (Fig. 6). Also, chlorogenic acid (130 mg kg-1) was the most abundant phenolic compound in the flesh, followed by isochlorogenic acid A $\left(60 \mathrm{mg} \mathrm{kg}^{-1}\right)$. Caffeic acid (200 mg kg-1) and isochlorogenic acid $\mathrm{C}\left(190 \mathrm{mg} \mathrm{kg}^{-1}\right)$ were observed in the skin but not in the flesh tissues. There was ca. 15-fold greater concentration of total phenolics in the skin compared to the flesh tissues. All the individual phenolic compounds increased in abundance during the initial period (up to $c a .55 \mathrm{~d}$ ) of storage and tended to decline thereafter. Contrary to the old 'Covington' roots in Experiment 1, no significant effect of 1-MCP was observed on the phenolic compounds in the fresh roots in Experiment 2.

\section{DISCUSSION}

\section{Effect of 1-MCP on decay and weight loss}


The economic losses in sweetpotato postharvest chain are estimated to range between 35-95 $\%$ in developing countries ${ }^{14}$. These losses are attributed mainly to decay and weight $\operatorname{loss}^{4}$. From studies on different sweetpotato cultivars stored under East African marketing conditions, it was noted that the weight loss was associated with physiological disorders ${ }^{15}$ and therefore the authors recommended that weight loss may be used to measure the postharvest loss of marketable value. A similar observation was made by van Oirschot ${ }^{4}$. This relationship was also confirmed in the current study where a striking correlation between sweetpotato decay and weight loss was noted. The high rate of decay and weight loss in sweetpotato are attributed to the high moisture content $(50-81 \%)$ and water loss through the delicate skin, respectively. The high moisture content renders the roots vulnerable to a number of microbial infections. The rot symptoms showing on the roots in the current study implicated that Rhizopus stolonifer could possibly be the causal pathogen. Disease screens by Yencho et al. ${ }^{2}$ showed that 'Çovington' is typically susceptible to Rhizopus soft rot but resistant to Fusarium wilt and stem rots caused by Fusarium oxysporum. R. stolonifer causes a watery soft rot at the ends of injured roots giving off fermentative odours.

Although ethylene inhibits sprout growth in sweetpotato, there is growing evidence that it promotes both weight loss and decay ${ }^{7,11,16}$ and this may be through its interaction with the crop-pathogen system. Ethylene-induced decay characteristically initiates from the root $\operatorname{tip}^{7,11,16}$. As an ethylene binding inhibitor, 1-MCP effect on physicochemical changes in crops is normally evaluated in the context of its antagonistic response to ethylene. 1-MCP may therefore be expected to counteract ethylene-induced decay. In an unpublished report, it was found that the application of 1-MCP $\left(1.0 \mu \mathrm{L} \mathrm{L}^{-1}\right)$ during the curing of sweetpotato cvs. Beauregard and Evangeline achieved $10 \%$ lower incidence of rot symptoms in the early periods (up to $133 \mathrm{~d}$ ) of storage compared to the control (Villordon A, Pers. com). However, 
the effectiveness against decay diminished during subsequent storage. In another study, Cheema et al. ${ }^{12}$ found no diseases when four weeks old sweetpotato cvs. Bushbuck and Ibees were treated with 1 -MCP $\left(625 \mathrm{~nL} \mathrm{~L}^{-1}, 24 \mathrm{~h}\right)$ and stored at $25{ }^{\circ} \mathrm{C}$ for just four weeks. Thus, the timing of 1-MCP application is important, it being more effective in most crops soon after harvest ${ }^{17}$. The efficacy of $1-\mathrm{MCP}$ against sweetpotato decay is further corroborated by a separate report by Villordon ${ }^{16}$ in which 'Beauregard' roots treated with $1-\mathrm{MCP}\left(1.0 \mu \mathrm{L} \mathrm{L}^{-1}, 1\right.$ h) showed no signs of disease during 3 months' storage.

\section{Effect of 1-MCP on sweetpotato respiration rate and sprout growth}

Ethylene boosted respiration rate in sweetpotato cv. Covington by about $1.5-2.0-$ fold $^{7}$ as was similarly the case in potato ${ }^{6}$ and onion ${ }^{9}$. Therefore, the inhibition of ethylene perception by $1-$ MCP may be expected to also produce the opposite respiratory effect. For instance, 1-MCP suppressed respiration rate in potato ${ }^{18}$. $1-\mathrm{MCP}$ also marginally reduced respiration in the sweetpotato cvs. Bushbuck and Ibees compared to untreated roots ${ }^{12}$. The expected decline in respiration rate by 1-MCP treatment was, however, not evident in the current study.

1-MCP inhibited sprout growth in onions stored at 4 or $12{ }^{\circ} \mathrm{C}$ but not at $20^{\circ} \mathrm{C}^{19}$, suggesting temperature dependence of 1-MCP effectiveness against sprouting. Thus, the low temperature storage may explain the low respiration rate as well as the inability of sprouts to grow in the sweetpotato roots studied. Low temperature may therefore be sufficiently inhibitory to sprout growth in sweetpotato and that, 1-MCP effect on sprout development may better be evaluated at higher storage temperatures.

\section{Effect of 1-MCP on non-structural carbohydrates in sweetpotato}

1-MCP inhibits ethylene induced sugar accumulation in potatoes ${ }^{5,6,8}$. In contrast to potato, however, ethylene reduces the concentration of monosaccharides in sweetpotato ${ }^{7}$. 1-MCP 
would therefore be expected to elicit the opposite effect on sugars in sweetpotato. The lack of effect on the sugars in any of the 'Covington' roots in the present study also confirm limited interference with natural metabolism at the low storage temperature of $15^{\circ} \mathrm{C}$.

Initial concentration of the reducing sugars and sucrose compare very well with the respective values obtained by Yencho et al. ${ }^{2}$, except maltose which was not detected. Maltose is scarcely present in raw sweetpotatoes. The presence of maltose mainly results from starch hydrolysis, especially during cooking. Thus, the detection of maltose in the roots of cv. Covington in Experiment 1 may be attributed to the breakdown of starch during the long-term storage. During storage, all the monosaccharides significantly declined $(\mathrm{P}<0.001)$ in both tissues of the cv. Covington while sucrose content remained relatively stable. Such decline in sugar levels in sweetpotato has been linked with harvest age. Four sweetpotato cultivars harvested at 5 months' maturity lost total soluble solids by up to $53.4 \%$ (depending on cultivar) during storage while there were increases in samples harvested earlier at three or four months' maturity ${ }^{20}$. Thus, the late harvest of the cv. Covington in the present study may explain the declining trend in the sugars during storage. The consistent decline in the content of maltose alongside fructose and glucose in the cv. Covington also suggests restricted starch hydrolysis.

\section{Effect of 1-MCP on phenolics in sweetpotato}

Phenolic compounds play anti-fungal role and therefore the effectiveness of 1-MCP against rot symptoms may also be through its interaction with phenolics in sweetpotato. 1-MCP has been shown to inhibit phenolics biosynthesis in many crops $^{21}$ as opposed to ethylene-induced accumulation of phenolics. No published work is available in the literature on how 1-MCP mediates the biosynthesis of phenolics in the tissues of sweetpotato. As observed in 
Experiment 1 of the current study, the suppression of phenolics by 1-MCP is consistent with observations in other crops. Significant suppression of phenolics by 1-MCP, however, occurred only in the early days of storage and was short-lived. This may explain the earlier observations by Cheema et al. ${ }^{12}$, Harper ${ }^{15}$ and Villordon (pers. comm) and suggests the need for repeated application of 1-MCP during storage for full effectiveness. Phenolics content in the middle and distal sections of the roots were the most suppressed, leaving a net higher balance of individual phenolic compounds in the proximal tissues. It may therefore be speculated that the promoted concentration of phenolics in the proximal tissues by 1-MCP provides a mechanistic context to explain its suppression of ethylene-induced tip decay symptoms.

There is a marked similarity in the phenolics distribution pattern in the cvs. Covington and Beauregard since ${ }^{22}$ also observed that chlorogenic acid dominated in the flesh (cortex and pith) tissues of the sweetpotato cv. Beauregard, followed by isochlorogenic acid A. That these major phenolic compounds were highly concentrated in the proximal root sections suggests that they are likely related to natural disease resistance.

\section{CONCLUSION}

At $15{ }^{\circ} \mathrm{C}, 1-\mathrm{MCP}$ had no effect on respiration in sweetpotato cv. Covington. However, there was significant improvement in the longevity of the stored roots. 1-MCP treatment may have anti-decay effect and reduce weight loss. Therefore, storage trials which involve the use of continuous ethylene supplementation to inhibit sprout growth may be combined with 1-MCP to alleviate ethylene-induced weight loss and decay. Furthermore, the study reveals that 1MCP suppresses phenolic compounds but that the effect is brief. The distribution of phenolic compounds and dry matter in sweetpotato is skewed towards the proximal segments of the roots. The dominance of phenolics, especially the antifungal compounds chlorogenic acid and 
its isomers in the proximal sections may perform a role in both defence against diseases and the commonly observed proximal sprouting in sweetpotato.

\section{ACKNOWLEDGEMENT}

The work was funded by the Commonwealth Scholarship Commission, UK (GHCA-201020), while Barfoots of Botley, Sussex, UK, supplied sweetpotatoes for the experiments.

\section{REFERENCES}

1. Brinely TA, Truong VD, Coronel P, Simunovic J. and Sandeep KP, Dielectric properties of sweet potato puree at $915 \mathrm{MHz}$ as affected by temperature and chemical composition. Int J Food Prop 11: 158-172 (2008).

2. Yencho GC, Pecota KV, VanEsbroeck Z, Holmes GJ, Thorton AC, Truong V-D and Schultheis JR, 'Covington Sweetpotato'. HortScience 43(6): 1911-1914 (2008).

3. Rees D, Kapinga R, Mtunda K, Chilosa D, Rwiza E, Kilima M, Kiozya H and Munisi R, Damage reduces both market value and shelf-life of sweetpotato: A case study of urban markets in Tanzania. Tropical Science 41: 142-150 (2001).

4. van Oirschot QEA, Storability of sweetpotatoes under tropical conditions: Physiological and sensory aspects. Cranfield University, Cranfield. PhD Thesis, (2000)

5. Prange RK, Daniels-Lake BJ, Jeong J-C and Binns M, Effects of ethylene and 1methylcyclopropene on potato tuber sprout control and fry color. Am J Potato Res 82 (2): $123-128(2005 b)$. 
6. Foukaraki SG, Cools K, Chope GA and Terry LA, Impact of ethylene and 1-MCP on sprouting and sugar accumulation in stored potatoes. Postharvest Biol Technol 114: 95103 (2016b).

7. Amoah RS, Landahl S and Terry LA, The timing of exogenous ethylene supplementation differentially affects stored sweetpotato roots. Postharvest Biol Technol 120: 92-102 (2016).

8. Foukaraki SG, Cools K, Chope GA and Terry LA, Effect of the transition between ethylene and air storage on postharvest quality in six UK-grown potato cultivars. $J$ Hortic Sci Biotechnol 89 (6): 599-606 (2014).

9. Downes K, Chope GA and Terry LA, Postharvest application of ethylene and 1methylcyclopropene either before or after curing affects onion (Allium cepa L.) bulb quality during long-term cold storage. Postharvest Biol Technol 55: 36-44 (2010).

10. Cools K, Chope GA and Terry LA, Short treatment with ethylene and 1methylcyclopropene in combination prior to storage is sufficient to reduce sprout growth in onion (Allium cepa L.). Acta Horticulturae 945: 297-301 (2011).

11. Arancibia RA, Main JA and Clark CA, Sweetpotato tip rot incidence is increased by preharvest applications of ethephon and reduced by curing. HortTechnology 23: 288-293 (2013).

12. Cheema MUA, Rees D, Colgan RJ, Taylor M, Westby A, The effects of ethylene, 1-MCP and AVG on sprouting in sweetpotato roots. Postharvest Biol Technol 85: 89-93 (2013).

13. Chope GA, Terry LA, White PJ, The effect of 1-methylcyclopropene (1-MCP) on the physical and biochemical characteristics of onion cv. SS1 bulbs during storage. Postharvest Biol and Technol 44: 131-140 (2007a).

14. Rees D, van Oirschot QEA, Kapinga RE, Mtunda K, Chisola D, Mbilinyi LB, Rwiza EJ, Kilima M, Kiozya H, Amour R, Ndondi T, Chottah M, Mende D, Tomlins KI, Aked J, 
Carey EE, Extending root shelf-life during marketing by cultivar selection, in Sweetpotato Post-Harvest Assessment: Experiences from Tanzania, ed. by Rees, D, Van Oirschot, Q and Kapinga, R, Natural Resources Institute, Chatham, UK (2003).

15. Sweetpotato Post-Harvest Assessment: Experiences from East Africa, ed. by Rees D, Kapinga R and van Oirschot Q (eds), International Potato Centre, Lima, Peru (1998).

16. Villordon AQ, Differential response of 'Beauregard' sweetpotato storage roots to ethephon, 1-methylcyclopropene and water submergence treatments. HortScience 47 (9): S324 (Abstr.) (2012).

17. Harper G, 1-Methylcyclopropene: a review of its use on potato tubers. Sutton Bridge Storage Research. Potato Council, pp. 8 (2015).

18. Foukaraki SG, The effects of ethylene and 1-MCP on potato tuber physiology and biochemistry. PhD Thesis, Cranfield University, UK, pp. 96-132 (2012).

19. Chope GA, Understanding the mechanisms behind onion bulb dormancy in relation to the potential for improved onion storage, $\mathrm{PhD}$ Thesis, Cranfield University, UK, pp. 102$122(2006)$.

20. Adu-Kwarteng E, Sakyi-Dawson OE, Ayernor GS, Truong VD, Shil FF, Daigle K, Variability of sugars in staple-type sweetpotato (Ipomoea Batatas) cultivars: The effects of harvest time and storage. Int J Food Prop 17: 410- 420 (2014).

21. Saltveit ME, Effect of 1-methylcyclopropene on phenylpropanoid metabolism, the accumulation of phenolic compounds, and browning of whole and fresh-cut 'iceberg' lettuce. Postharvest Biol Technol 34: 75-80 (2004).

22. Padda MS, Phenolic composition and antioxidant activity of sweetpotatoes [Ipomoea batatas (L.) Lam]. PhD Thesis, Louisiana State University, pp. 28-39, 85-92 (2006). 
Figures

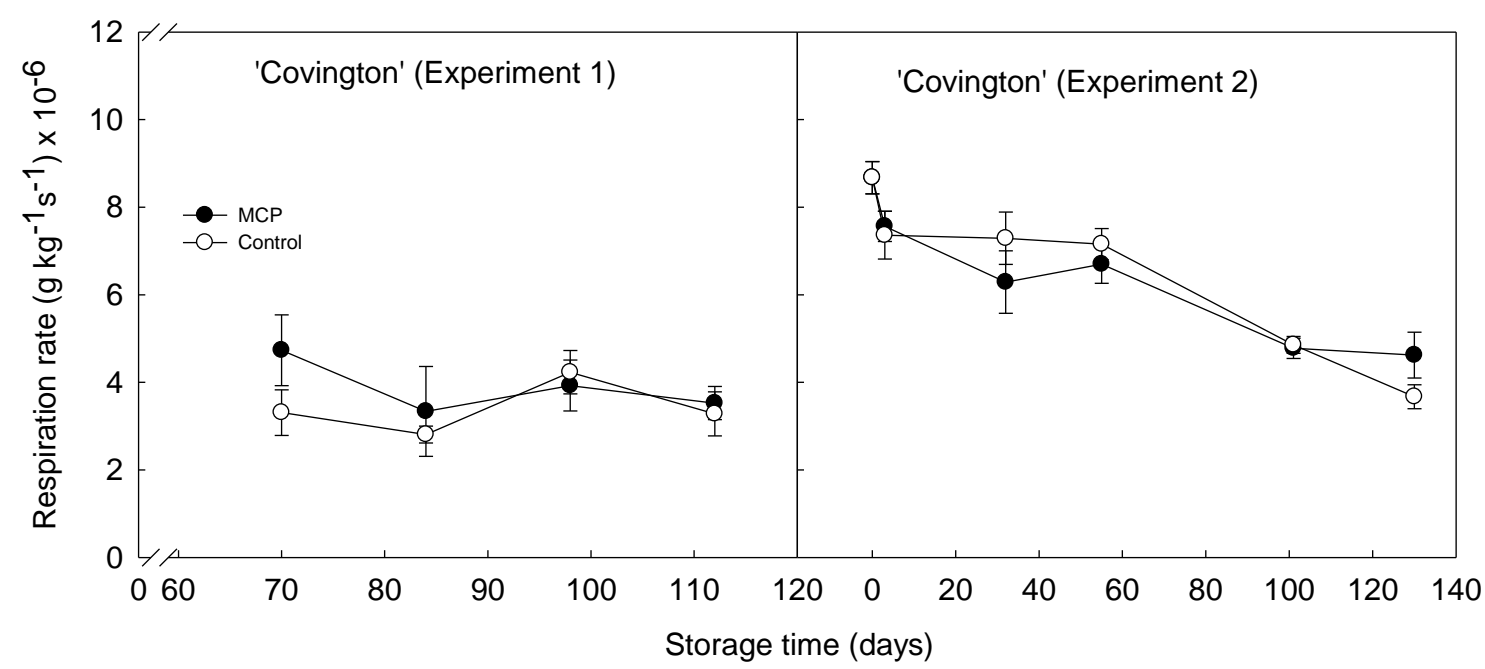

Figure 1. Respiration rate $\left(\mathrm{g} \mathrm{kg}^{-1} \mathrm{~s}^{-1}\right)$ of sweetpotato during storage with or without $1 \mu \mathrm{L}^{-1} 1$ MCP. Respiration rate was measured in terms of the evolution of $\mathrm{CO}_{2}$. Each data point is the mean of three replicated treatments consisting of three roots per replicate for Experiment 1 $(n=9)$ and four roots per replicate for Experiment 2, respectively. Roots in Experiment 1 and Experiment 2 were treated $255 \mathrm{~d}$ and $22 \mathrm{~d}$, respectively, after harvest. The bars represent \pm standard error of the mean. 


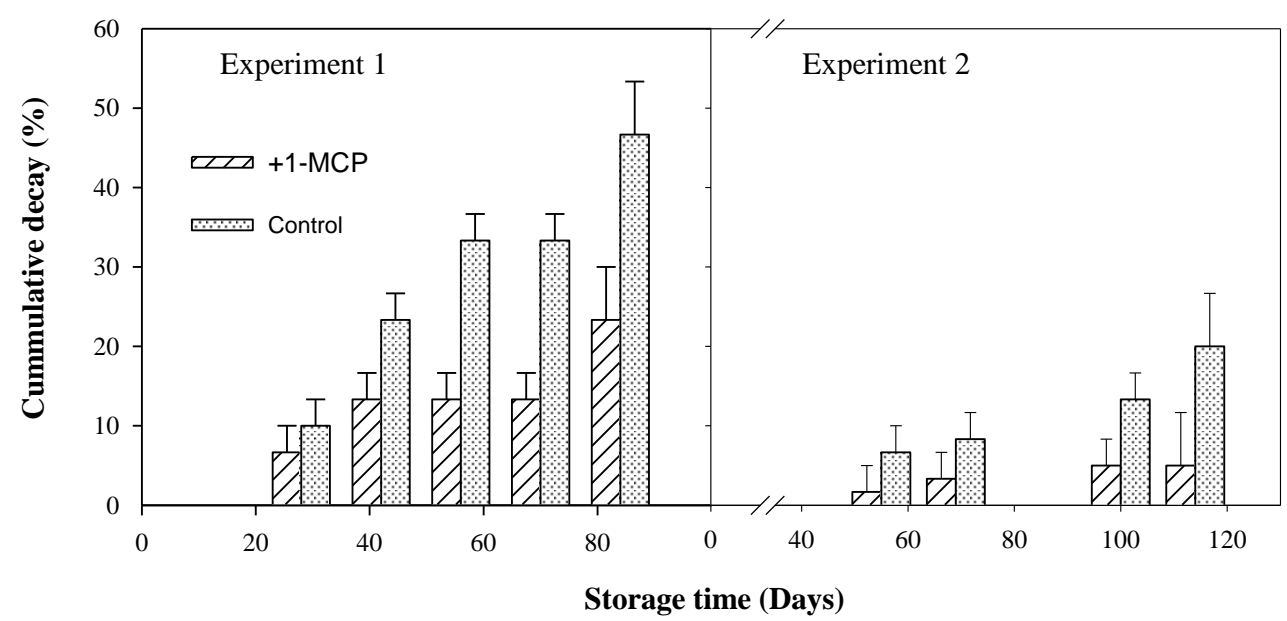

Figure 2. Decay of sweetpotato cv. Covington during storage at $15{ }^{\circ} \mathrm{C}$ with or without $1.0 \mu \mathrm{L} \mathrm{L} \mathrm{L}^{-1} 1-\mathrm{MCP}$. Each data point is the mean of three replicated treatments containing 10 roots per replicate in Experiment 1 and 20 roots per replicate in Experiment 2, respectively. Roots in Experiment 1 and Experiment 2 were treated with 1-MCP $255 \mathrm{~d}$ and $22 \mathrm{~d}$, respectively, after harvest. The bars represent \pm standard error of the mean. 


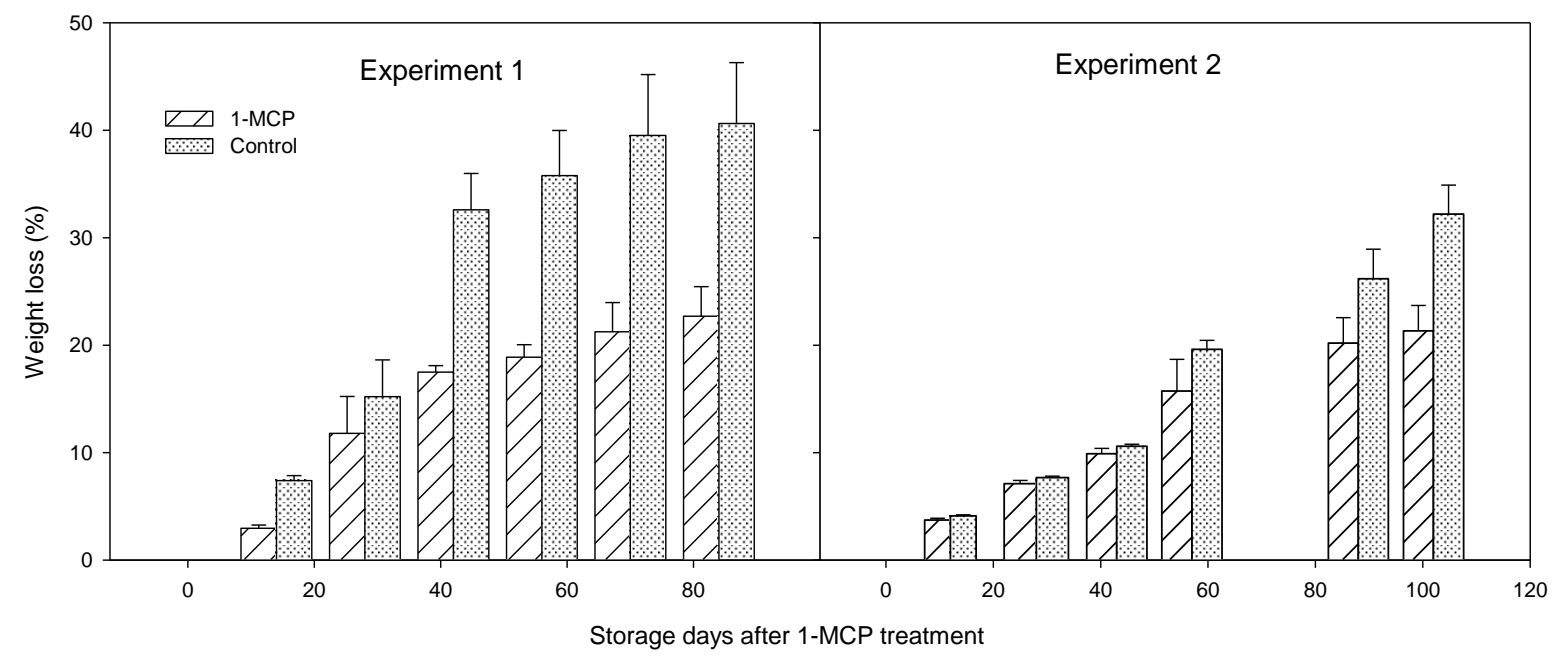

Figure 3. Weight loss of sweetpotato cv. Covington during storage at $15{ }^{\circ} \mathrm{C}$ with or without $1.0 \mu 1 \mathrm{~L}^{-1} 1-\mathrm{MCP}$. Each data point is the mean of three replicated treatments containing 10 roots per replicate in Experiment 1 and 20 roots per replicate in Experiment 2, respectively. Roots in Experiment 1 and Experiment 2 were treated with 1-MCP $255 \mathrm{~d}$ and $22 \mathrm{~d}$, respectively, after harvest. The bars represent \pm standard error of the mean. 


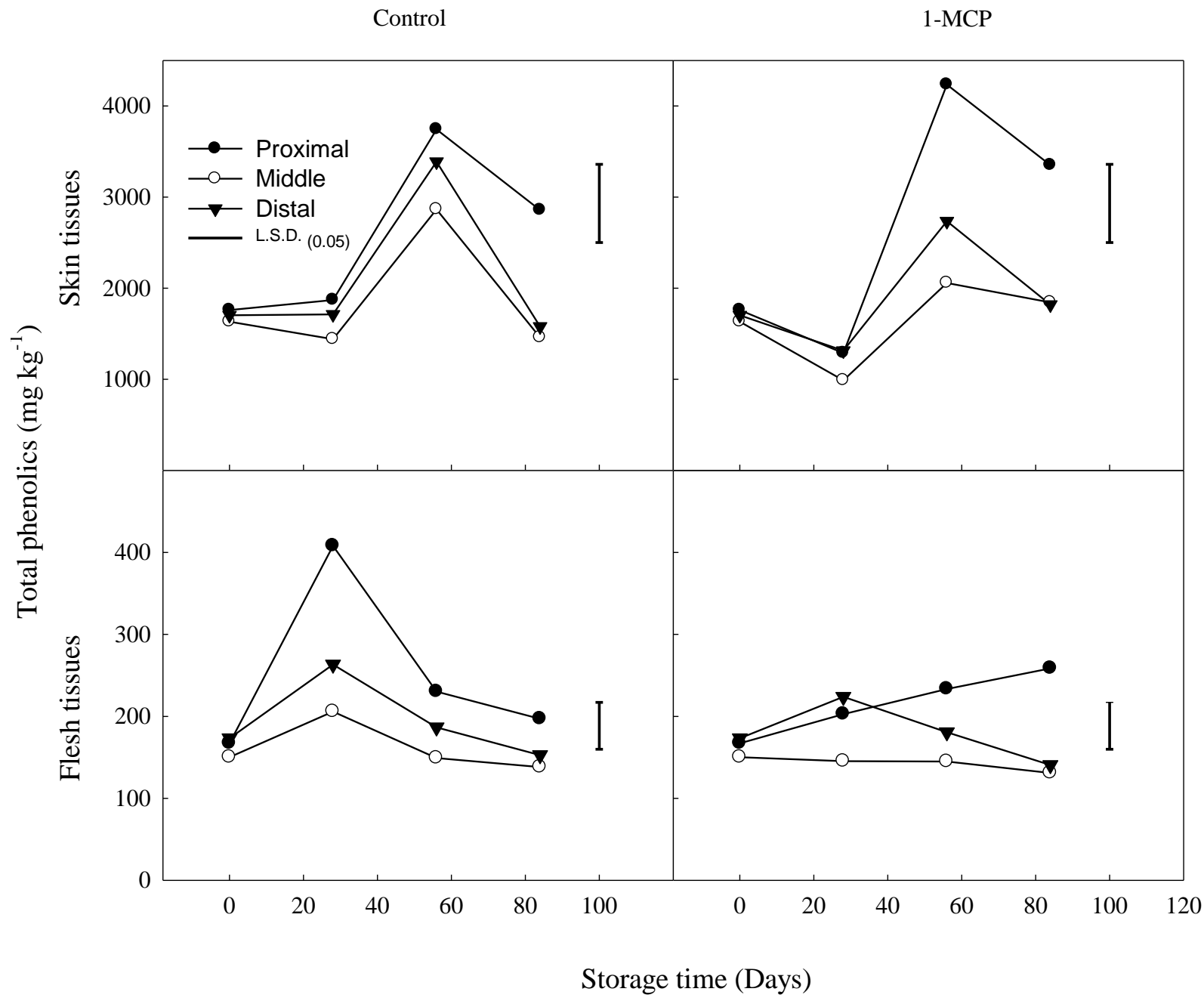

Figure 4. Spatial concentrations of total phenolics (chlorogenic acid equivalence of fresh weight basis) in sweetpotato $\mathrm{cv}$. Covington (Experiment 1) during storage at $15{ }^{\circ} \mathrm{C}$ with or without $1 \mu 1 \mathrm{~L}^{-1} 1$-MCP. Each data point is the mean of three replicated treatments consisting of three roots per replicate $(n=9)$. The roots were treated $255 \mathrm{~d}$ after harvest. The bars represent L.S.D. (0.05). 


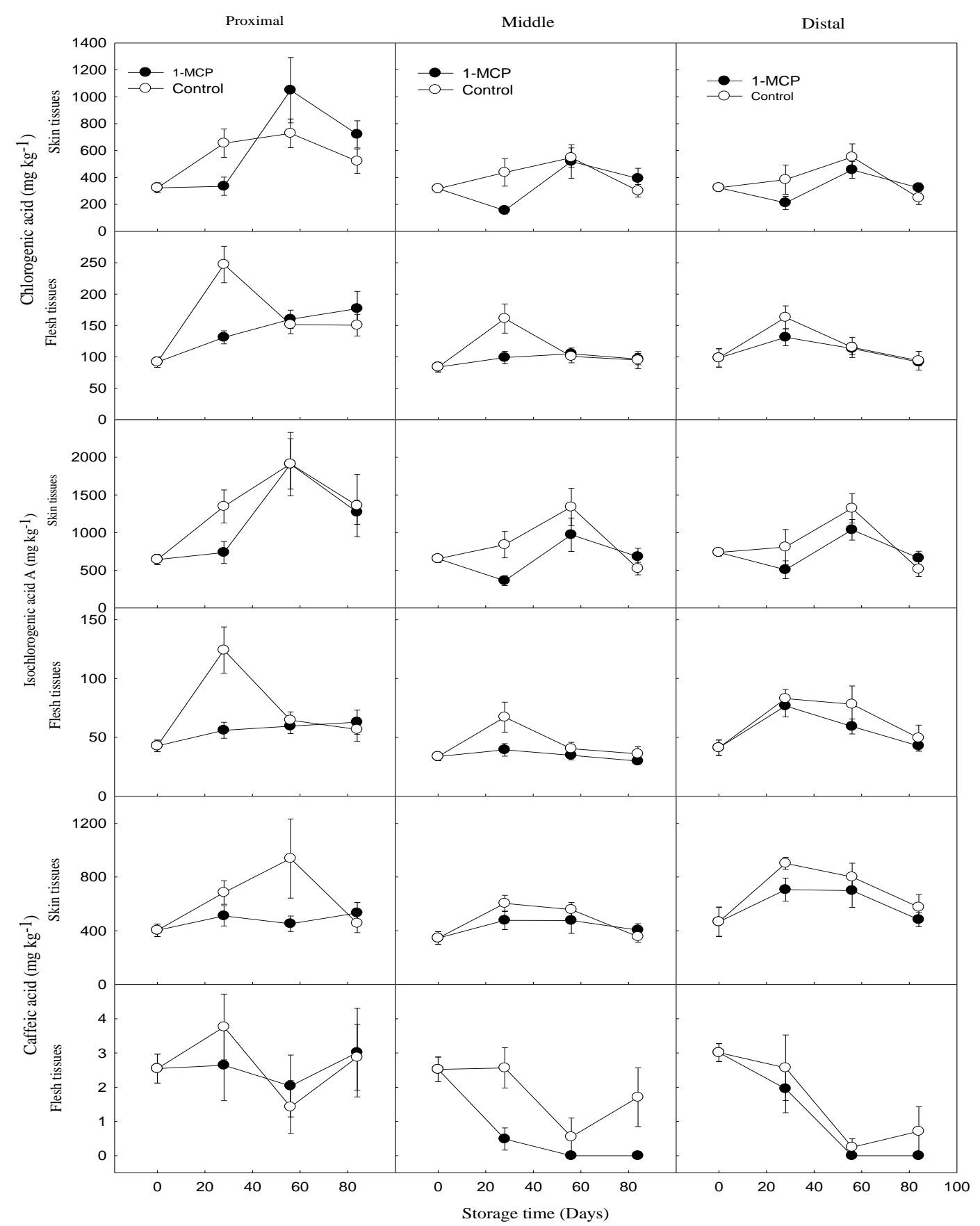

Figure 5. Spatial concentrations of chlorogenic acid, isochlorogenic acid A and caffeic acid in sweetpotato cv. Covington (Experiment 1). All concentrations are expressed as chlorogenic acid equivalence on fresh weight basis. Each data point is the mean of three replicated treatments consisting of three roots per replicate $(n=9)$. The roots were treated $255 \mathrm{~d}$ after harvest. The bars represent \pm standard error of the mean. 
Skin tissues

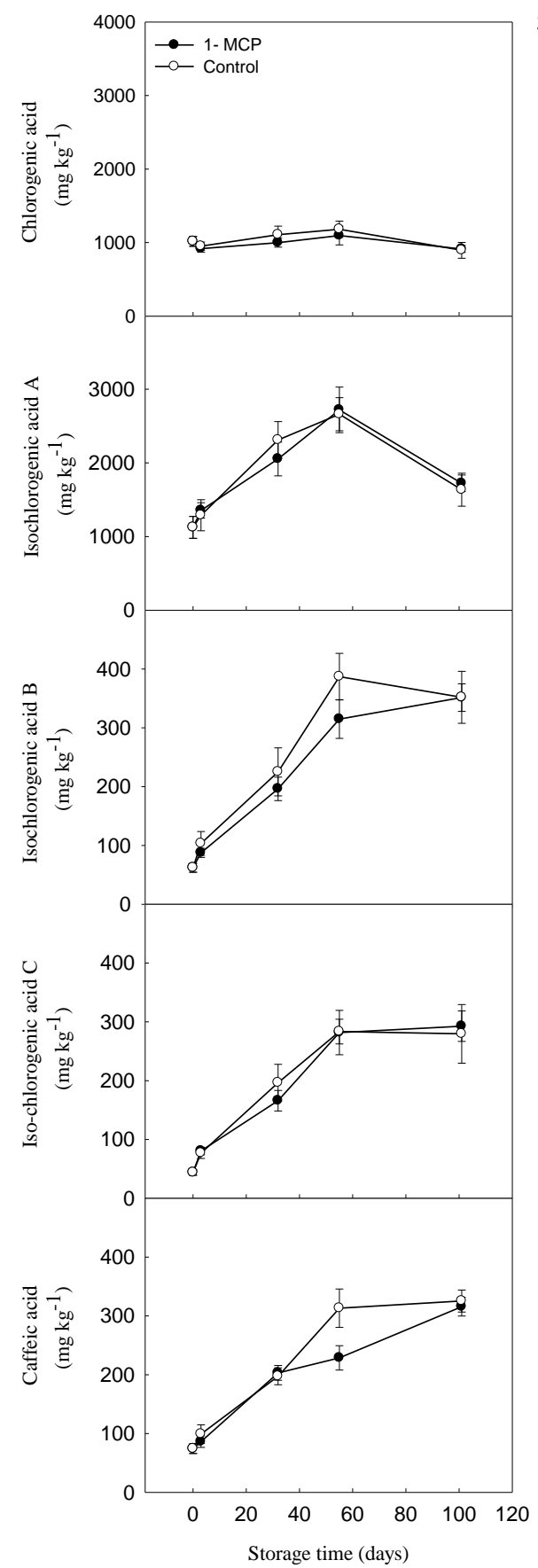

Flesh tissues

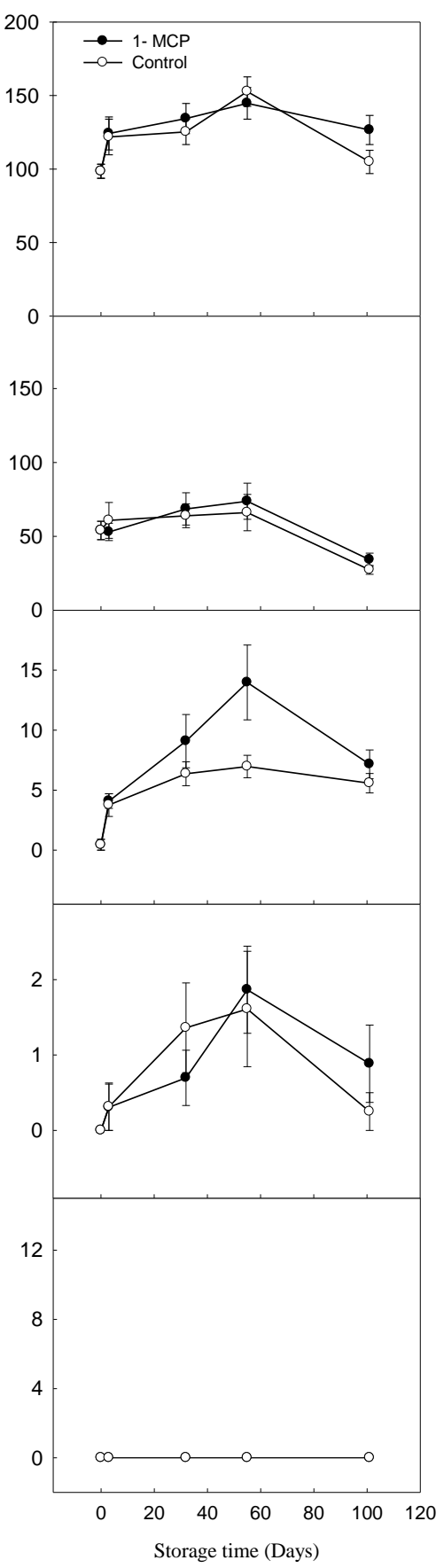

Figure 6. Spatial concentration (fresh weight basis) of phenolic compounds in sweetpotato cv. Covington during storage at $15{ }^{\circ} \mathrm{C}$ with or without $1 \mu \mathrm{L} \mathrm{L}-1$ 1-MCP (Experiment 2). Each data point is the mean of three replicated treatments consisting of four roots per treatment $(n=12)$. The roots were treated $22 \mathrm{~d}$ after harvest. The bars represent \pm standard error of the mean. 


\section{Supplementary Figures}
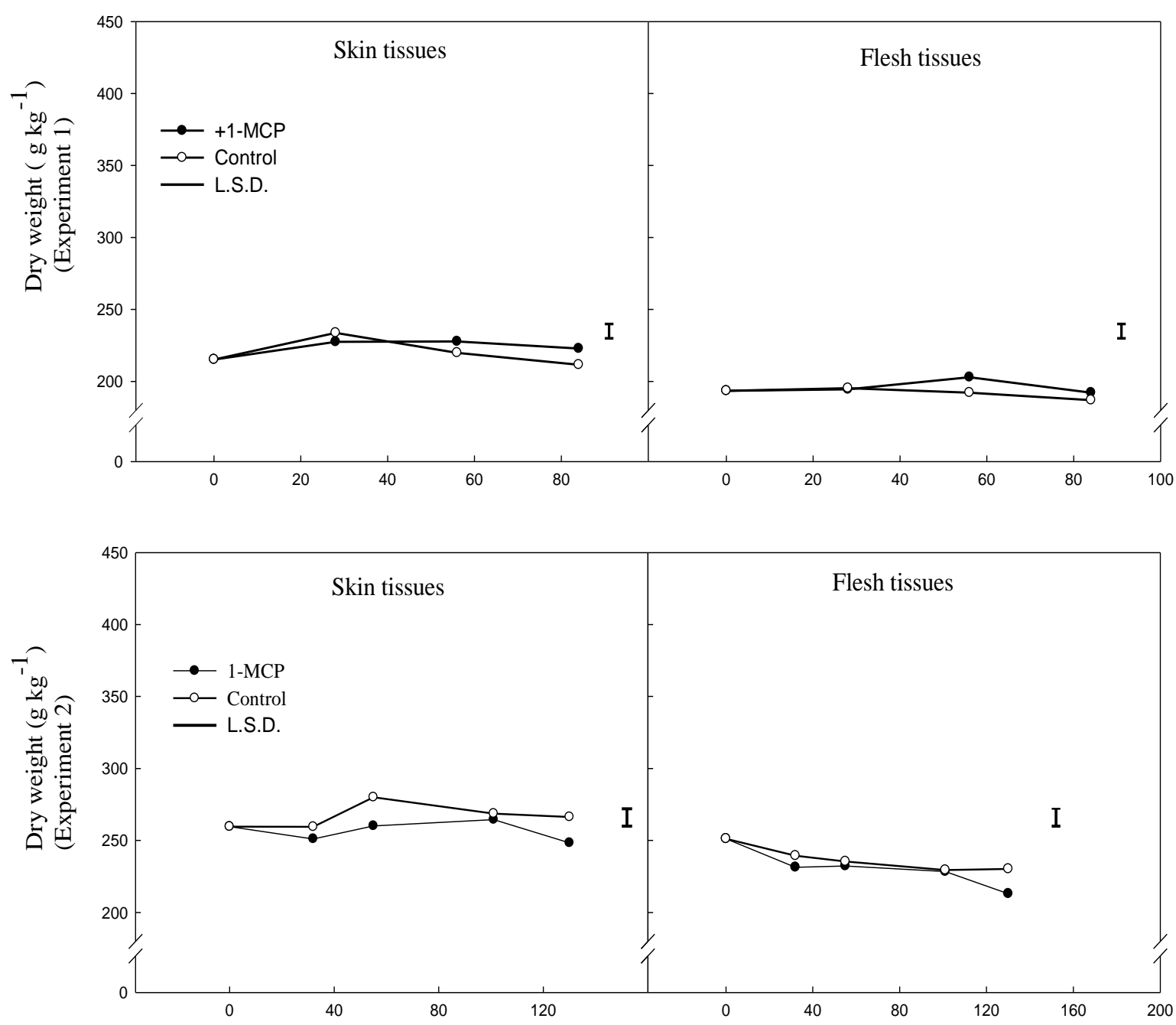

Storage time (Days)

Supplementary Figure 1. Dry weight of sweetpotato cv. Covington during storage at $15{ }^{\circ} \mathrm{C}$ with or without $1 \mu 1 \mathrm{~L}^{-1} 1-\mathrm{MCP}$. Each data point is the mean of three replicated treatments containing three roots per treatment in Experiment $1(n=9)$ and four roots per treatment in Experiment $2(\mathrm{n}=12)$. Roots in Experiment 1 and Experiment 2 were treated $255 \mathrm{~d}$ and $22 \mathrm{~d}$ respectively, after harvest. The bars represent L.S.D. (0.05). 


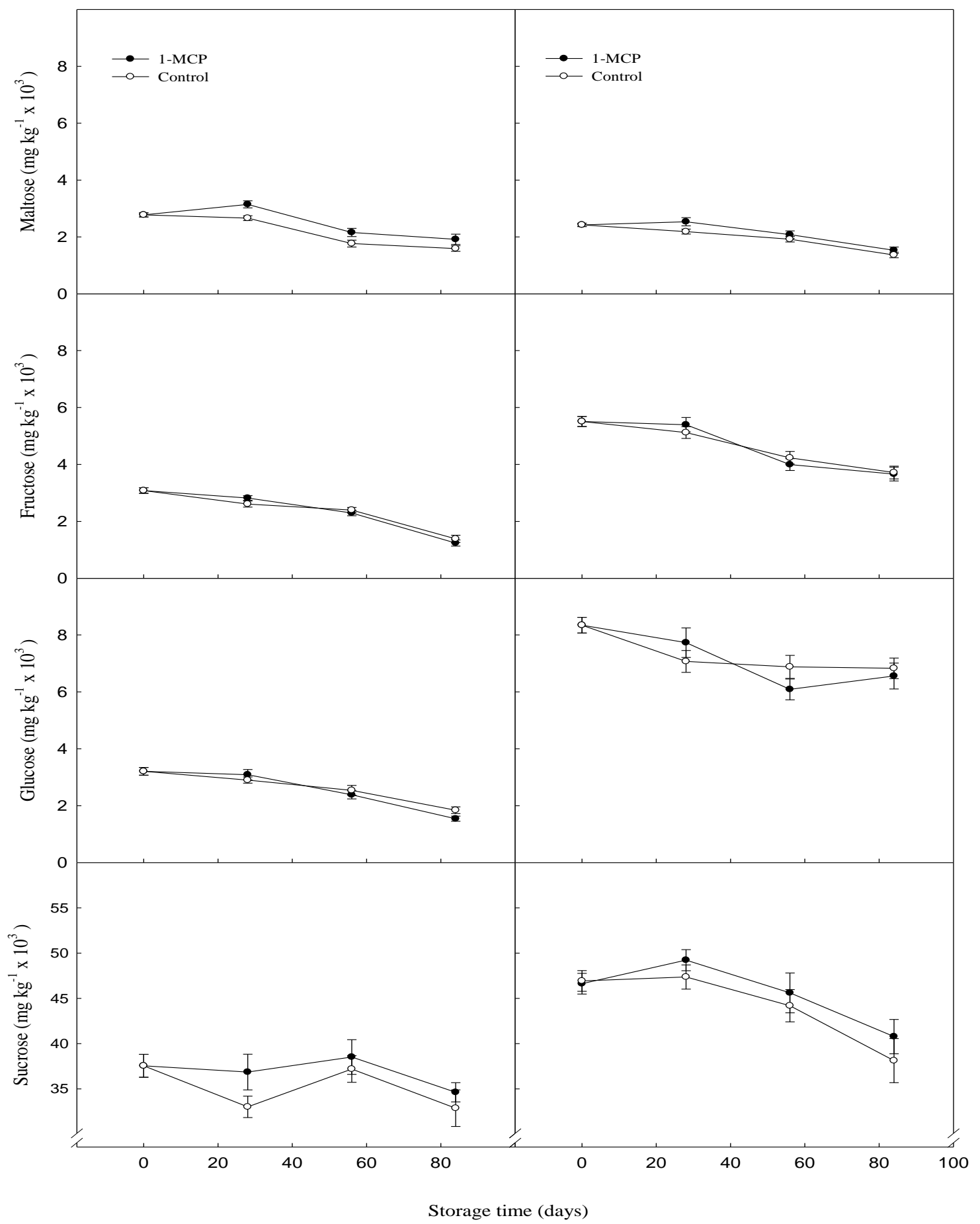

Supplementary Figure 2. Non-structural carbohydrates (fresh weight basis) in the tissues of sweetpotato cv. Covington (Experiment 1) during storage at $15{ }^{\circ} \mathrm{C}$ with or without $1 \mu 1 \mathrm{~L}^{-1} 1$-MCP. Each data point is the mean of three replicated treatments consisting of three roots per replicate $(n=9)$. The roots were treated $255 \mathrm{~d}$ after harvest. The bars represent \pm standard error of the mean. 


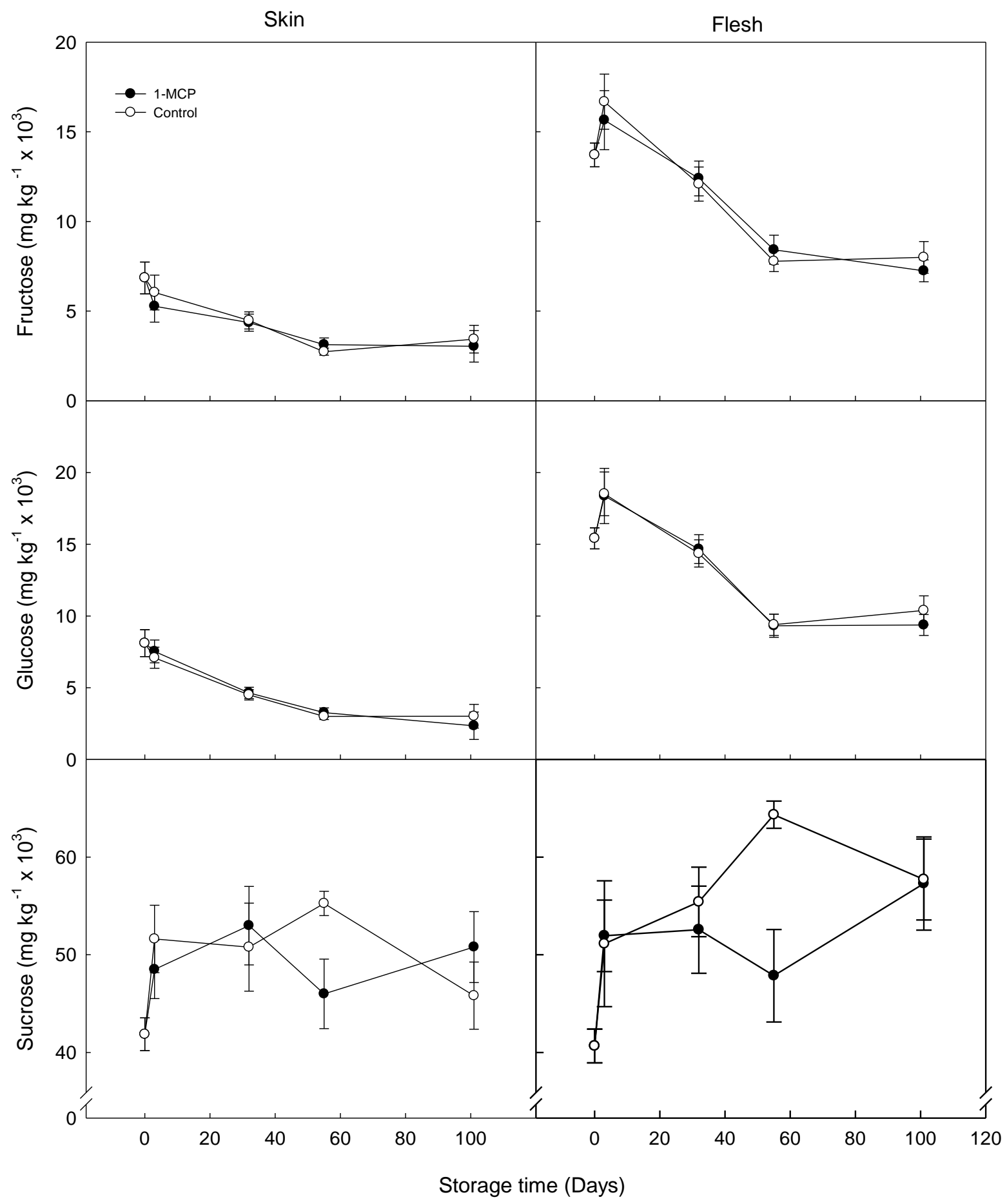

Supplementary Figure 3. Non-structural carbohydrates in the tissues of sweetpotato cv. Covington (Experiment 2) during storage at $15^{\circ} \mathrm{C}$ with or without $1 \mu 1 \mathrm{~L}^{-1} 1-\mathrm{MCP}$. Each data point is the mean of three replicated treatments consisting of four roots per replicate $(n=12)$. The roots were treated $22 \mathrm{~d}$ after harvest. The bars represent \pm standard error of the mean. 


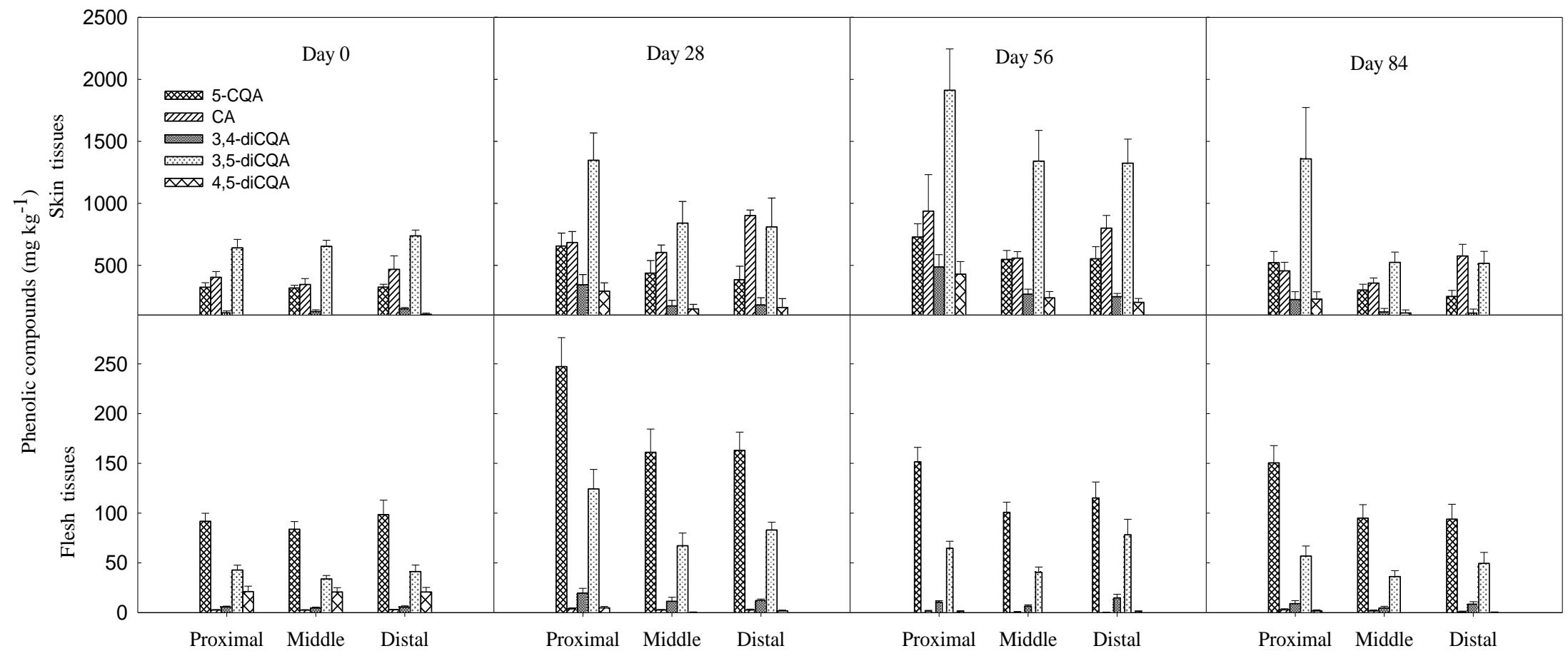

Supplementary Fig. 4. The spatio-temporal concentrations (measured as chlorogenic acid equivalence on fresh weight basis) of individual phenolic compounds in sweetpotato cv. Covington during storage at $15{ }^{\circ} \mathrm{C}$ without 1-MCP treatment (Experiment 1). Each data point is the mean of three replicated treatments consisting of three roots per replicate $(n=9)$. The bars represent \pm standard error of the mean. 


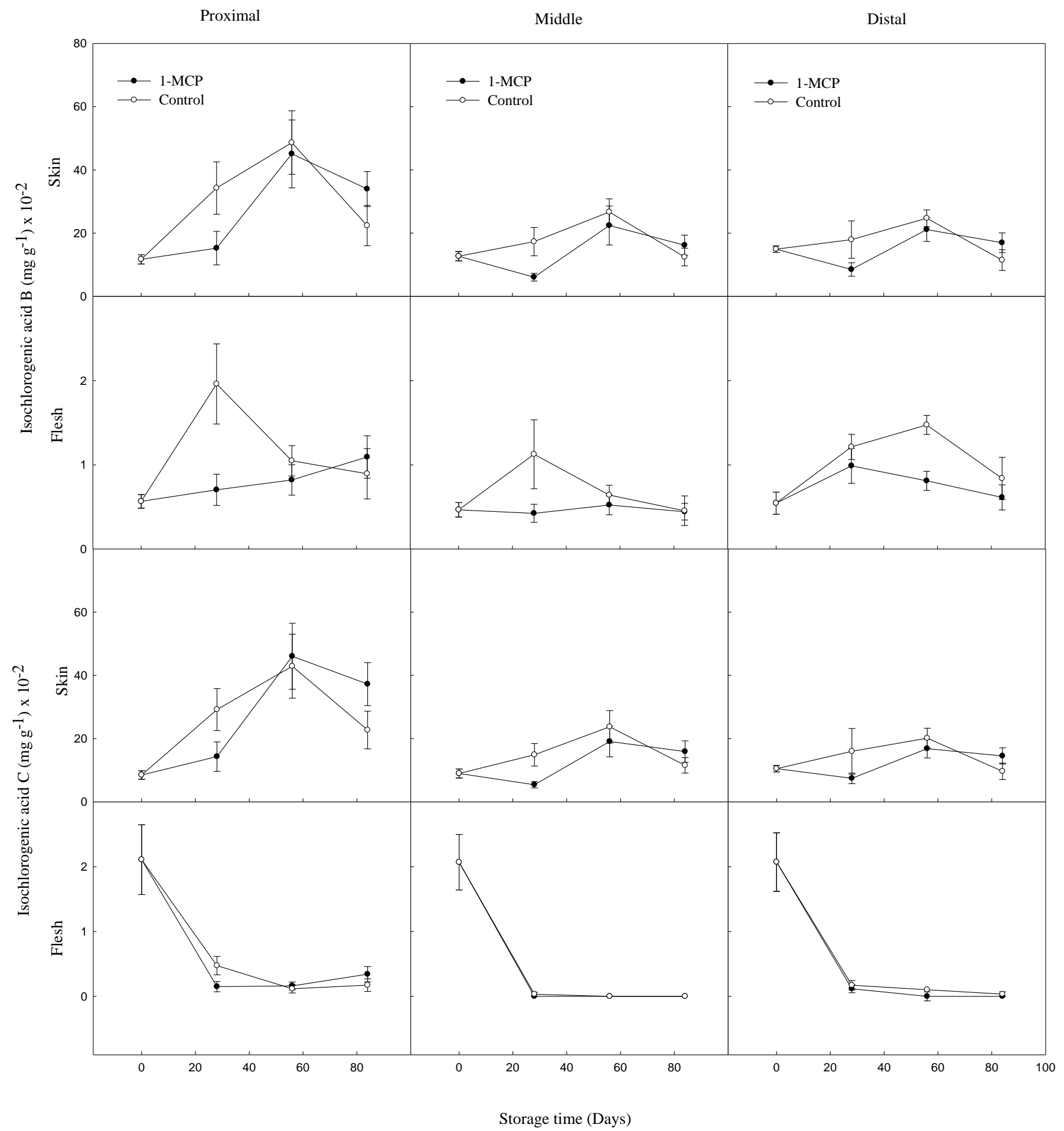

Supplementary Figure 5. Isochlorogenic acid B and isochlorogenic acid C concentration in sweetpotato cv. Covington (Experiment 1) during storage at $15{ }^{\circ} \mathrm{C}$ with or without $1 \mu 1 \mathrm{~L}^{-1} 1$ MCP. All concentrations were measured as chlorogenic acid equivalence on fresh weight basis. Each data point is the mean of three replicated treatments consisting of three roots per 
replicate $(n=9)$. The roots were treated $255 \mathrm{~d}$ after harvest. The bars represent standard \pm error of the mean. 